\title{
Land subdivision: How students determine equal area
}

\author{
Aan Hendroanto \\ Universitas Ahmad Dahlan, J1. Ringroad Selatan, Tamanan, Bantul, Daerah Istimewa \\ Yogyakarta \\ *Corresponding e-mail: aan.hendroanto@pmat.uad.ac.id
}

\begin{abstract}
This study aims to support student's understanding of the properties of a bisector related to the area of the triangle. A context and a set of activities is design based on Realistic Mathematics Education (RME) theory to develop students' understanding and to engage them in meaningful activities. Design research is chosen as the research approach with two cycles of experiment. A context of land subdivision problem was selected to activate students' prior knowledge and to bring them into the activities. At First, the activities is presented in small group of mathematics students and in the regional mathematics competition as one of the final question for the finalists. Then, the second cycle is conducted in the classroom with students from mathematics education program in Universitas Ahmad Dahlan. The result showed that none of the students and finalists in the competition were able to solve the question because they do not have idea how to do land subdivision. They cannot use their prior knowledge of bisector to solve the problem. After revising the activities, in the classroom, all groups in the class were able to solve the problem. These activities are land subdivision with three different levels of difficulties and purposes.
\end{abstract}

Keywords: bisector, design research, land subdivision, realistic mathematics education, triangle

How to Cite: Hendroanto, A. (2020). Land subdivision: How students determine equal area. International Journal on Education Insight, 1(1), 21-28. http:// dx.doi.org/10.12928/ijei.v1i1.2088

\section{INTRODUCTION}

Many people keep questioning the importance of mathematics in their life and argue that it does not related directly in their life. Most people do not know the application of mathematics in daily life even though mathematics indeed has influence since it determines our ability and competences. In fact, the goal of mathematics education is to help students implementing mathematical concepts in their future life (Freudenthal, 1991); (K.W, 2011). This kind of competency is called mathematical literacy ( (Heuvel-Panhuizen, 1998); ( $\mathrm{J}$, 2006); (A, 2018)). Based on the statement of (OECD, 2012) (OECD, PISA 2012 Assessment and Analytical Framework: Mathematics, Reading, Science, Problem Solving and Financial Literacy., 2012), mathematical literacy is about students' ability to identify, organize, solve, and interpret mathematical problems encountered in daily life. In Indonesia, students' mathematical literacy is still considered low according to the result of PISA 2015 in which Indonesian students are only in 9th row from the bottom of the ranking table. Therefore, mathematics education in Indonesia should focus more on how to develop students' mathematical literacy.

One of the solutions to support students' mathematical literacy is implementing Realistic Mathematic Education in the class ( Freudenthal, 1991); (Sembiring, 2014); (A, 2018)). RME suggests mathematics to be taught not as a ready subject but as a result of students' exploration and activity ( 
(Heuvel-Panhuizen, 1998); (Zulkardi, 2002)). Many studies have confirmed that RME indeed had positive impact on students' mathematical literacy ( (Widjaja, 2011); (Waluya, 2018); (Rosita, 2018); (Sutisna, 2019)). This is because RME has three principle which are 1) Didactical phenomenology, 2) Guided reinvention, and 3) Emergent modelling (Gravemeijer, 2003). Didactical phenomenology suggests that the classroom activity should begin from and based on a context. This context can be a real world problem or a fictional story that can lead students to find big ideas and mathematical concepts ( (Gravemeijer, 2003); (A, 2018)). By using contexts, students will understand the concepts in a more meaningful way. As a result, they can fully master the concept and last longer in their mind than using a conventional way of teaching ( (Zulkardi, 2002); (Wijaya, 2012); (White, 2017)).

One of the concept in mathematics is special line in a triangle such as bisector. Bisector lines of a triangle is a line connecting the vertices of the triangles to the mid-point of the opposite sides. Students do not have to struggle to understand this. They easily identify the line in seconds after the teacher explains the concepts. However, this does not last longer as after days and weeks past, they begin to doubt what a bisector of a triangle is and their properties. Therefore, this study aims to design classroom activities for students to explore the concept of bisector line through meaningful contexts.

\section{RESEARCH METHOD}

This study uses design research as research approach to achieve the purpose which is designing activities for students to explore the concept of bisector line in a triangle. Design research is choosen because it allows us to study deeper into students' mind. In design research, it is like we are trying to be the students. Design research consist of three stages of developing process: 1) Preliminary design 2) Teaching Experiment, and 3) Retrospective analysis (Akker, 2006). In the first stage, a series of activities are designed based on the literature study and as a result of didactical phenomenology process. Two cycles of teaching experiment are conducted to test the design so that the activities can be revised. The last stage is retrospective analysis in which the design is analyzed based on the result of teaching experiment.

The subject of the first teaching experiment in this study is three groups of 3 students from regional mathematics competition. In the second cycle, the subject is 30 students from plane geometry course in Universitas Ahmad Dahlan. The data is collected from students' works and presentation. Additional data is from observation, video recording, and interview.

\section{RESULTS AND DISCUSSION}

This study consists of three stages of designing process. Therefore, the following explanations and descriptions are based on these three stages which are 1) Preliminary Design, 2) Teaching Experiment, and 3) Retrospective analysis.

\section{Cycle 1 of Design Research}

Preliminary Design

The preliminary design of the activity is by giving the students an open activity of with the context of land division. The context is about a king who wants to split his land for his two sons. Therefore, the land must be divided evenly and fairly. The task is students have to figure out how they divide the land effectively and efficiently. Figure 1 shows the land. 


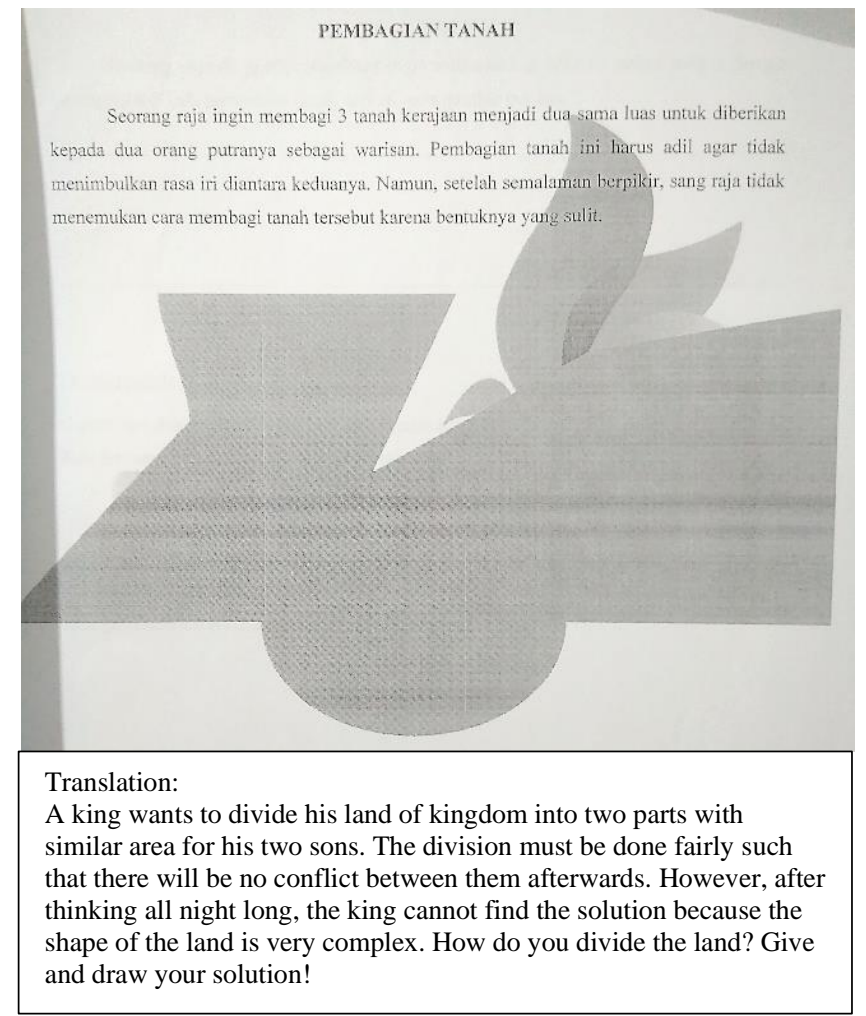

Figure 1. The land of kingdom

This design is then tested in the final mathematics literation contest in UAD as a question for three teams in the final stage. The result will be discussed in the next section.

\section{Teaching Experiment}

Because this is a mathematics competition than teacher or observer cannot do scaffolding. Hence, the model employed in this teaching experiment is discovery learning. We gave the students time to discuss the problem with their friends and the result is then presented in front of the audience.

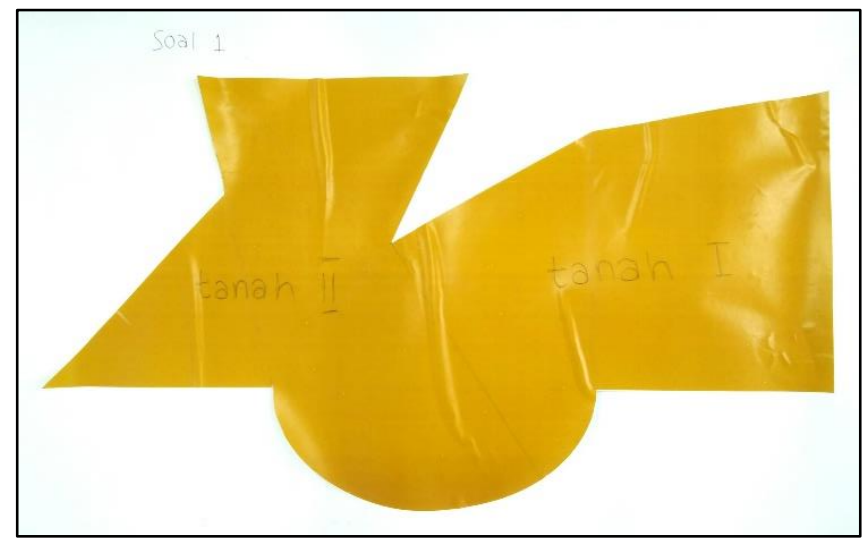

Figure 2. The answer of the first group

Figure 2 shows the answer from the first group in which they were trying to divide the land into two parts. However, when they are asked the reason, they 
failed to convince everyone. They claimed that the just estimate roughly without calculation the land with the black line. Hence, they just conclude that that the two lands have the same area. From this fact, it seemed that this group did not know how to do the split. Group 2 also did something similar with group 1.

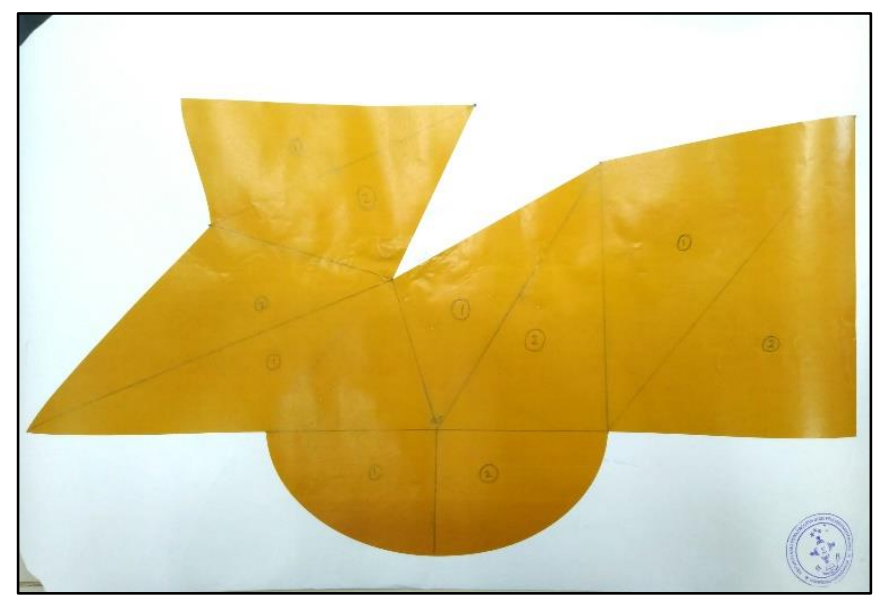

Figure 3. The answer of the third group

Group 3 has different approach shown in Figure 3. They divided the land into several parts and then they share the parts for the sons. This strategy seemed better than the first two groups. However, they also failed to proof that the part they share have the same area or equal. But this strategy is more accurate than just roughly estimate without a reference. They assume these parts are equal in which they use them as reference. But, they also realize that the answer are not good enough and there must be a better solution for it.

\section{Retrospective Analysis}

The result of the first cycle turned out to be not as we have expected. No students can find the reasonable solution. The given solution is just randomly arranged parts and they estimated or assume the parts have the same area. This is not the correct answer. None of the groups came up with the idea of triangle and the properties of bisector line. Therefore, the activity was then revised to adjust students' ability.

\section{Cycle 2 of Design Research}

Preliminary Design

The activity in the first cycle is too open and discovery learning seemed not to work for students. Therefore, we revise the activity into a more engaging and teacher was more involved during the discussion. We created preliminary problems before they do the complex one. Figure 4 represents the problem. 


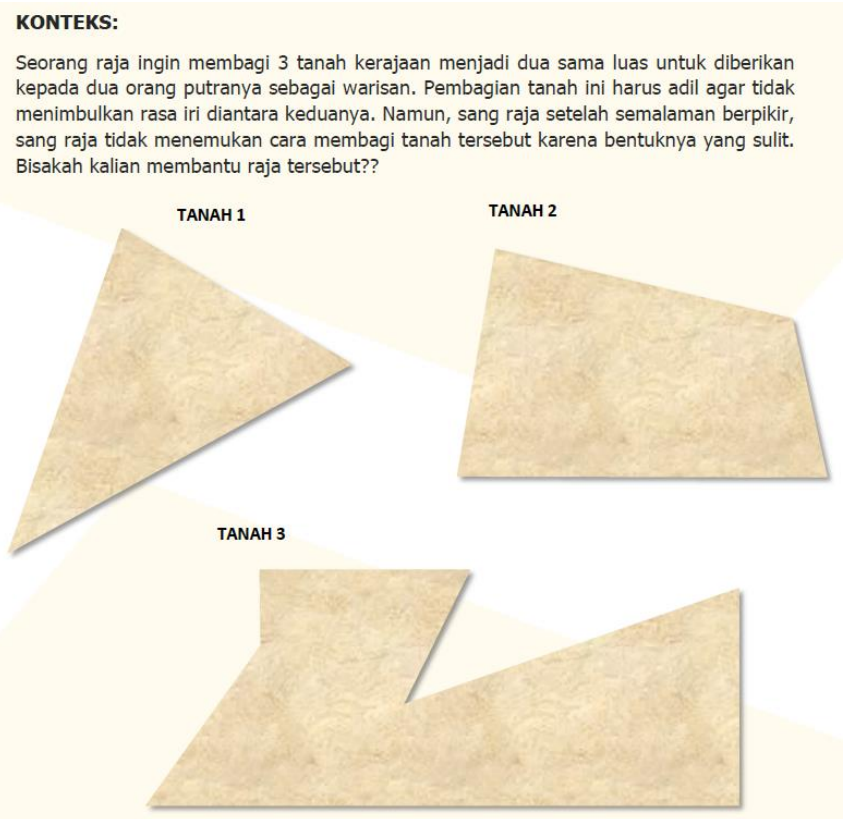

Figure 4. Problems in the second cycle

There are three lands starting from the simplest one (triangle) into a more complex (Four sided land) and the almost-similar problem from the cycle 1 . We hypothesized that students will come up with the idea of bisector from the first activity when the land is formed like a rectangle. This design is then tested in the geometry course in 2018 with approximately 25 students.

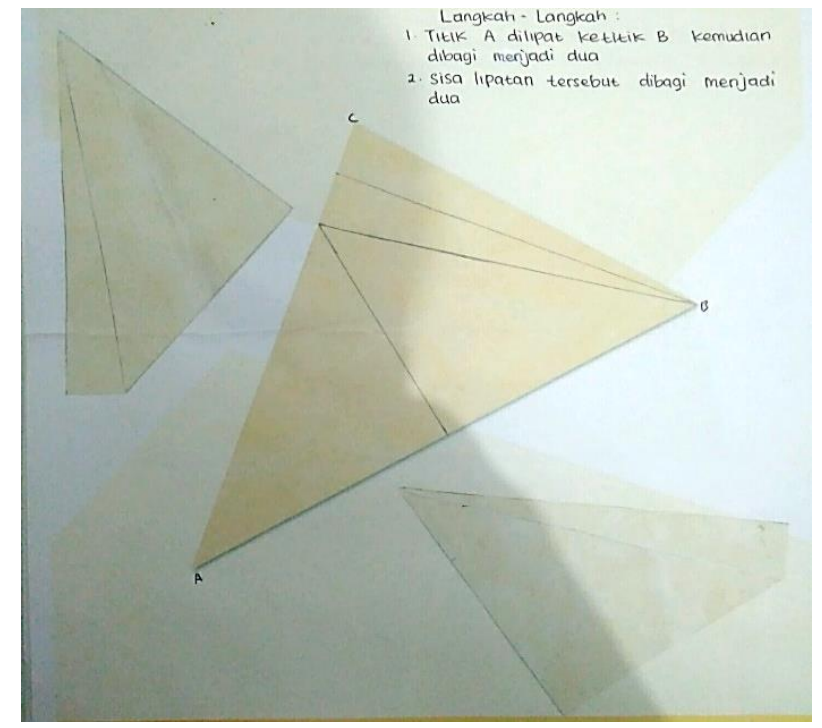

Figure 5. Answers for problem about Land 1 from the first group

\section{Teaching Experiment}

The experiment begin with teacher giving the problem to the students and they work in small groups of 3 students to solve them. Figure 5 shows the answer of the first group for problem in land 1. The firs group did the split by folding the paper so that the side meet to the next side. Then, they draw a line 
to indicate the mark on the land. After they folded them, they cut them and glue to the upper left corner and bottom-right corner. The have the same area but the teacher asked them again "How do you fold the land, it is impossible" and "how would you join the two lands into one again". They cannot answer the teacher and then they got confused.

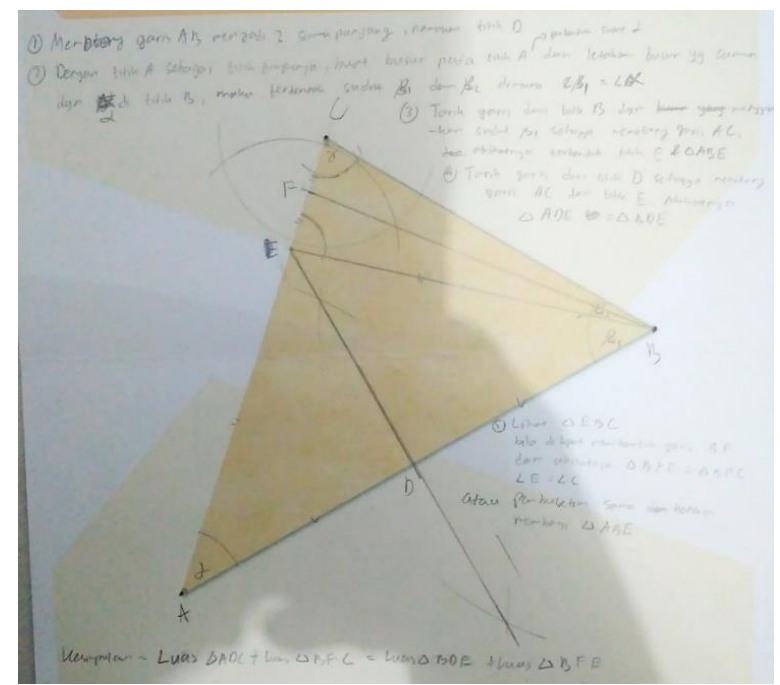

Figure 6. Answers for problem about Land 1 from the second group

The second group also have an interesting answer shown in Figure 6. They did not fold the land but they find the midpoint of each side by using a procedure of drawing a perpendicular bisector using a compass and a ruler. The mark of compass can be seen in Figure 6 proves that they use them as a reference to divide the land. However, they still split the land into 4 parts and separate from each other. However, they did not find a better way of dividing the land so that there will be only 2 main lands.

\section{Retrospective Analysis}

The results shows that the students come up with the properties of bisector in activity in which suggest that the activity played a better role than the first problem given to the students. By getting the idea of bisector, students then moved to the next problem of land. Figure 7 shows some of the answers.

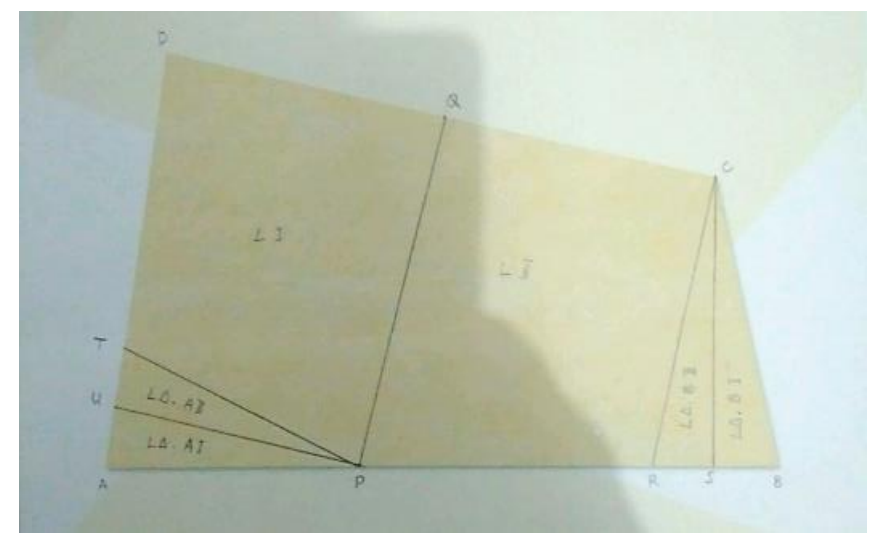

Figure 7. Answers for problem about Land 1 from the second group 
They easily divide the land by finding the bisector and forming triangles. However, the result answers are not efficient. Since they can actually divide the land into two triangles only. After discussing the problem with the teacher they realized a better way of splitting the land so that the parts were not separated from each other.

\section{CONCLUSION}

Based on the discussion above we can conclude that the activity bring the students to the concept of bisector in a triangle by splitting the land. The first problem was not effective since it needs more guidance and too open for the students. But, after simplifying the problem, they can find various solution to the problems.

The second and third problems are also can be solved by the students although the solution are not elegant and still the parts are separated from each other.

\section{ACKNOWLEDGEMENT}

Thank to Universitas Ahmad Dahlan for funding this research and also provide unending support. Students and participants in this research who spend time to give their response and hardwork for providing constructive feedback for author.

\section{REFERENCES}

Akker, G. J. (2006). Introducing educational design research. In Educational design research, (Vol. 1, pp. 3-7).

Freudenthal, H. (1991). Revisting Mathematics Education: China Lectures. New York: Kluwer Academic Publishers.

Gravemeijer, B. K. (2003). Chapter 4: A Hypothetical Learning Trajectory on Measurement and Flexible Arithmetic. Journal for Research in Mathematics Education, 51-66.

Hendroanto, A. (2018). Didactical Phenomenology Untuk Mengembangkan Aktivitas Pembelajaran Geometri Bidang Dengan Pendekatan Pendidikan Matematika Realistik. In Prosiding Seminar Nasional Pendidikan Matematika Etnomatnesia.

Heuvel-Panhuizen, M. v. (1998). Theory into practice in Mathematics Education. Kristiansand, Norway: Faculty of Mathematics and Sciences. Realistic Mathematics Education as work in progress.

J, D. L. (2006). Mathematical literacy for living from OECD-PISA Perspective.

K.W, G. (2011). Five Ideas For 21st Century Math Classrooms. American Secondary Education, 108-166.

OECD. (2012). PISA 2012 Assessment and Analytical Framework: Mathematics, Reading, Science, Problem Solving and Financial Literacy. Paris: OECD Publishing.

OECD. (2015). Draft Collaborative Problem Solving Framework. (OECD Publishing) Retrieved 08 24, 2016, from http://www. oecd. org/pisa/pisaproducts/Draft\% 20PISA\% 202015\% 20Collaborative\% 20Problem\% 20Solving\% 20Framework\% 20.pdf.

Rosita, W. A. (2018). Discovery Learning-PMRI in Improving Mathematics Literacy of Junior High School Students. Unnes Journal of Mathematics Education Research, 7(1), 35-39. 
Sembiring, K. (2014). Pendidikan Matematika Realistik Indonesia (PMRI): Perkembangan dan Tantangannya. Journal on Mathematics Education, 1(1), 11-16.

Sutisna, P. A. (2019). The Influence of the Realistic Mathematics Education Approach and Early Mathematical Ability to Mathematical Literacy. . Int. J. Multidiscip. Curr. Res, 6, 798-801.

Waluya, \&. B. (2018). Development of innovative problem based learning model with PMRI-scientific approach using ICT to increase mathematics literacy and independence-character of junior high school students. Journal of Physics: Conference Series, 983.

White, L. A. (2017). Building A 21st Century Mathematical Brain. Seminar Nasional Pendidikan Matematika Ahmad Dahlan. Yogyakarta.

Widjaja, W. (2011). Towards mathematical literacy in the 21st century: perspectives from Indonesia. Southeast Asian mathematics education journal, 1(1), 75-84.

Wijaya, A. (2012). Pendidikan matematika realistik: Suatu alternatif pendekatan pembelajaran matematika. Yogyakarta: Graha Ilmu.

Zulkardi. (2002). Developing a learning environment on realistic mathematics education for Indonesian student teachers. Twente: University of Twente. 